Wright State University

CORE Scholar

6-2006

\title{
Substratum as a Driver of Variation in Periphyton Chlorophyll and Productivity in Lakes
}

Yvonne Vadeboncoeur

Follow this and additional works at: https://corescholar.libraries.wright.edu/biology

Part of the Medical Sciences Commons

\section{Repository Citation}

Vadeboncoeur, Y. (2006). Substratum as a Driver of Variation in Periphyton Chlorophyll and Productivity in Lakes. Journal of the North American Benthological Society, 25 (2), 379-392.

https://corescholar.libraries.wright.edu/biology/582

This Article is brought to you for free and open access by the Biological Sciences at CORE Scholar. It has been accepted for inclusion in Biological Sciences Faculty Publications by an authorized administrator of CORE Scholar. For more information, please contact library-corescholar@wright.edu. 


\title{
Substratum as a driver of variation in periphyton chlorophyll and productivity in lakes
}

\author{
Yvonne Vadeboncoeur ${ }^{1}$ AND Jacob Kalff ${ }^{2}$ \\ McGill University, Biology Department, 1205 Dr. Penfield Ave, Montreal, Quebec, Canada H3A 1B1
}

Kirsten Christoffersen ${ }^{3}$

Freshwater Biological Laboratory, Helsingørsgade 51, DK-3400, Hillerød, Denmark

\author{
Erik Jeppesen ${ }^{4}$ \\ National Environmental Research Institute, Vejlsøvej 25 DK-8600, Silkeborg, Denmark and Department of \\ Plant Biology, University of Aarhus, Nordlandsvej 68, DK-8240 Risskov, Denmark
}

\begin{abstract}
Quantifying periphyton (attached algal) contributions to autotrophic production in lakes is confounded by properties of substratum that affect community biomass (as chlorophyll content) and productivity. We compared chlorophyll content and productivity of natural algal communities (phytoplankton, epipelon, epilithon, epixylon, and epiphyton) experiencing high $(>10 \%)$ incident radiation in lakes in the US, Greenland, and Quebec, Canada. Chlorophyll content and productivity differed significantly among regions, but they also differed consistently among communities independent of region. Chlorophyll content of periphyton on hard substrata (rocks and wood) was positively related to watercolumn total P (TP), whereas chlorophyll content of algae on sediment (epipelon) and TP were not significantly related. Chlorophyll content was up to $100 \times$ higher on sediments than on hard substrata. Within regions, chlorophyll-specific primary productivity was highest for phytoplankton and lowest for epipelon. Periphyton on hard substrata and on macrophytes (epiphyton) had similar rates of chlorophyllspecific productivity that were intermediate to those of epipelon and phytoplankton. Area-specific productivity of epipelon was 5 to $10 \times$ higher than area-specific productivity of periphyton on hard substrata. This broad geographic comparison indicates that, in low to moderately productive lakes under high-light conditions, algal communities have predictable differences in area-specific and chlorophyllspecific productivity based on substratum. As such, chlorophyll alone is an inadequate predictor of the relative contributions of different algal communities to total primary production. Our results highlight the importance of the relative abundance and spatial distributions of substrata in determining the role of the littoral zones in nutrient and energy cycles in lakes.
\end{abstract}

Key words: periphyton, microphytobenthos, epipelon, epixylon, epilithon, epiphyton, primary productivity, chlorophyll, spatial heterogeneity, lakes, Arctic.

Algae associated with surfaces (periphyton) can be responsible for a substantial proportion of whole-lake primary productivity and, thus, are a dynamic component of lake nutrient cycles (Axler and Reuter 1996, Hagerthey and Kerfoot 1998, Wurtsbaugh et al.

1 Present address: Department of Biological Sciences, Wright State University, 3640 Colonel Glenn Highway, Dayton, Ohio 45435 USA. E-mail:

yvonne.vadeboncoeur@wright.edu

${ }^{2}$ E-mail addresses: jacob.kalff@mcgill.ca

${ }^{3}$ kchristoffersen@bi.ku.dk

4 ej@dmu.dk
2001) and an underappreciated energy source in lake food webs (Hecky and Hesslein 1995). The phytoplankton chlorophyll:total $\mathrm{P}$ (TP) relationship is a cornerstone of predictive limnology (Dillon and Rigler 1974), but little progress has been made toward relating substratum-specific periphyton chlorophyll content to nutrient gradients in lakes (Cattaneo 1987, Smith 1998). The diversity of substrata upon which periphyton grow imposes methodological difficulties and causes high natural variability, both of which impede development of general relationships between periphyton and resources (Morin and Cattaneo 1992, 
Burkholder 1996, Vadeboncoeur et al. 2001, Hillebrand and Kahlert 2002). Artificial substrata such as clay tiles are an invaluable tool for cultivating homogenous periphyton assemblages that can be used in controlled experiments to isolate effects of nutrients, light, and grazing. However, there is still debate over how accurately periphyton from artificial substrata represent communities from natural substrata (Cattaneo and Amireault 1992). In addition, how to extrapolate from artificial substrata to ecosystem-level processes is not clear because littoral zones and stream beds are heterogeneous composites of diverse habitats for attached algae. We pooled data from periphyton assemblages growing on natural substrata from lakes in the upper peninsula of Michigan (US), Greenland (GL), and Quebec, Canada (QC) to compare substratum effects on periphyton chlorophyll content and productivity across broad geographic scales.

Different substrata have distinct spatial distributions within lakes and various degrees of physical and temporal stability (Sand-Jensen and Borum 1991, Lowe 1996, Wetzel 2001). Substratum also influences the availability of inorganic $\mathrm{P}, \mathrm{N}$, and $\mathrm{C}$ for associated algae (Burkholder 1996, Vadeboncoeur and Lodge 2000) and grazing pressure (Jones et al. 1997). The spatial distribution of substrata in lakes is nonrandom relative to depth and, hence, relative to light and physical disturbance (Rowan et al. 1992, Lowe 1996). Rocks and coarse woody debris are common in the high-light, high-disturbance areas close to shore. Macrophyte species segregate along the littoral-zone slope and shade algae in sediments (epipelon) but continuously provide new substrata for periphyton on plants (epiphyton) near the illuminated surface. Organic sediments accumulate in low-disturbance areas that often correspond to areas of low light, such as under macrophytes beds and in the deep littoral zone (Rooney et al. 2003). In spite of exceptions caused by variation in littoral slope, particle sorting driven by water movements leads to predictable patterns between substratum and depth (Lowe 1996).

Substrata also provide different physical and chemical habitats for associated algal communities (Pringle 1990, Burkholder 1996). Substrata vary in their surface roughness, which alters the effective surface area of a substratum, and in their physical stability. Epilithon (periphyton on rocks) and epixylon (algae on wood) grow on persistent, relatively stable surfaces. In contrast, sandy and muddy sediments are easily disturbed. Epipelic assemblages can stabilize unconsolidated sediments with extracellular polymers, but wave action and bioturbation can undermine the integrity of both algal mat and substratum (Yallop et al. 2000). Macrophytes provide relatively rigid, but usually ephemeral, surfaces for periphyton growth. This structural variability in substratum is expected to affect species composition of the different periphyton communities as well as the annual phenology of mat development (Pringle 1990, Sand-Jensen and Borum 1991, Michelutti et al. 2003). Differences in species composition among substrata may, in turn, lead to differential community responses to environmental gradients (Stevenson et al. 1985, Vinebrooke and Leavitt 1999).

Substratum also determines nutrient availability for attached algae (Burkholder 1996). In general, rocks and wood are not significant sources of $\mathrm{N}$ and $\mathrm{P}$ for associated periphyton (Vadeboncoeur and Lodge 2000), though $N$ and $P$ availability may depend on the degree of decomposition of the wood and the chemical characteristics of the rocks. Epiphyton can exploit nutrients leaked by macrophytes (Cattaneo and Kalff 1979, Carignan and Kalff 1982). The importance of macrophyte-derived $\mathrm{N}$ and $\mathrm{P}$ for epiphyton may depend on the trophic status of the lakes and the degree of senescence of the plant (Cattaneo and Kalff 1979, Burkholder and Wetzel 1989, 1990, Burkholder 1996), whereas photosynthesizing macrophyte leaves and epiphytes compete for inorganic C (Jones et al. 2002). Both groundwater and sediment pore water can have elevated inorganic N, P, and C concentrations (Hansson 1992, Hagerthey and Kerfoot 1998, Vadeboncoeur and Lodge 1998), reducing the need for epipelon and episammon (algae on sand) to rely on water-column nutrients (Carlton and Wetzel 1988). The concentration and availability of labile porewater nutrients may depend on both the chemical composition and organic matter content of unconsolidated sediments. These complex chemical attributes of substrata make it difficult to generalize about periphyton-nutrient relationships in lakes.

Variation in light, stability, and nutrients associated with substratum is expected to result in within-lake differences in productivity of periphyton assemblages as well as substratum-dependent responses to changes in water-column nutrients (Vinebrooke and Leavitt 1998, Nydick et al. 2004). Recognition of interactions among light availability, nutrients, and substratum contributed to the development of a conceptual model in which a succession of algal communities dominate whole-lake productivity across a eutrophication gradient (Sand-Jensen and Borum 1991, Wetzel 2001). The hypothesized succession begins with dominance by algae on sediments and rocks in oligotrophic lakes, progresses to macrophyte and epiphyton dominance in mesotrophic lakes, and finally to phytoplankton dominance in high-light-attenuation, high-nutrient, eutrophic lakes. This model predicts the directional 
response of different algal communities to changes in light and nutrients, but it does not explore the influence of substratum on algal productivity per se. We examine whether substratum is a consistent predictor of periphyton biomass (assessed as chlorophyll content) and productivity and how substratum effects are superimposed on regional and experimental nutrient gradients. We present data on epipelon, epilithon, epixylon, epiphyton, and phytoplankton from 18 lakes in the US, Greenland, and Quebec, Canada. We relate within- and among-substrata variation in area-specific chlorophyll content, areaspecific productivity, and chlorophyll-specific productivity to nutrient availability, specifically TP. In all study lakes, total N (TN):TP ratios were well in excess of Redfield ratios, indicating P limitation (Cattaneo and Kalff 1980, Carpenter et al. 2001, Vadeboncoeur et al. 2001). The data were collected originally to quantify whole-lake primary productivity (Vadeboncoeur et al. 2001, 2003), but here we analyze a subset of those data. We restricted our analysis to communities experiencing $>10 \%$ light to minimize the confounding effects of increased chlorophyll:biomass ratios associated with algae acclimated to very low light.

\section{Study Sites}

We compiled data for periphyton chlorophyll content and productivity on natural substrata in 3 geographic regions from 1992 to 2001. Detailed physical characteristics of the lakes are published elsewhere (Caning and Rasch 2000, Carpenter et al. 2001, Vadeboncoeur et al. 2003). In upper Michigan, US, we measured epipelon, epixylon, and phytoplankton in 5 steep-sided, oligotrophic lakes for 5 y (US lakes; Vadeboncoeur et al. 2001). The US lakes range from 1.7 to 3.4 ha in size and are in a forested landscape. Four of the lakes were experimentally fertilized for 3 summers. We treated each lake-year as an independent observation because each lake was fertilized at a different rate each year and returned to prefertilization conditions each spring (Carpenter et al. 2001). In Greenland, we collected phytoplankton, epipelon, epilithon, and epiphyton from 12 pristine lakes (GL lakes). Surface area of the GL lakes ranged from 0.2 to 2.5 ha, and all except the 3 deepest lakes froze to the bottom during the winter. Ten of the Greenland lakes were in a rocky moraine valley and were exceptionally clear, and 2 were on a marshy river delta near sea level. In Quebec, Canada, we sampled phytoplankton, epilithon, epiphyton, and epipelon in Lake Memphremagog (QC lake), which was the largest lake included in our study. Lake Memphremagog is $45 \mathrm{~km}$ long, up to $4 \mathrm{~km}$ wide, and has a mean depth of $20 \mathrm{~m}$. A north-south $\mathrm{P}$ gradient creates countervailing trends in macrophyte, epiphyte, and phytoplankton abundance (Cattaneo and Kalff 1980). We sampled 11 sites on Lake Memphremagog representing diverse habitats including steep rocky areas without macrophytes, exposed sandy shores with very low macrophyte biomass, and protected areas dominated by either Myriophyllum spicatum or native Potamogeton assemblages.

\section{Methods}

We collected these data originally to describe wholelake littoral-zone primary production with respect to pelagic primary production; more detailed descriptions of collection and analytical methods are published elsewhere (Carpenter and Kitchell 1993, Cottingham and Carpenter 1998, Vadeboncoeur and Lodge 1998, Vadeboncoeur et al. 2001, 2003).

\section{Sample collection}

Phytoplankton.--In the US lakes, we sampled phytoplankton with a van Dorn bottle from the middle of each lake at 100, 50, 25, and 10\% surface irradiance (Carpenter et al. 2001). In the GL lakes, we collected samples with a Heart Valve sampler from the middle of each lake at multiple depths and combined the samples to form an integrated water-column sample. In the QC lake, we collected phytoplankton with an integrated water sampler made from flexible tubing from the middle of each littoral site to a depth of $5 \mathrm{~m}$. We filtered the water onto glass-fiber filters (Whatman GF/F) for chlorophyll analysis, and froze the filters until analysis.

Periphyton.-We collected all periphyton samples using SCUBA or a mask and snorkel to ensure minimal disturbance of communities. We sampled each substratum where it was most abundant to estimate average periphyton chlorophyll concentration and productivity for each community.

We categorized rocks and wood together as hard substrata because both provided relatively stable attachment sites in the high-light, nearshore areas of lakes and were permanent relative to the generation times of attached algae. In the US lakes, we permanently marked 10 large logs dispersed around the perimeter of each lake. We sampled epixylon from the logs 3 to $7 \times$ per summer at depths of $\sim 0.5 \mathrm{~m}$, using a new spot on the log each time we sampled. We used a 60-cc syringe sampler fitted with a nylon brush to remove the periphyton in situ (Loeb 1981). We transported the slurries to the laboratory, and treated them as described below for GL and QC periphyton. In the GL lakes, we collected rocks $(n=3)$ from the average 
depth of the lakes. GL lakes were small and extremely clear, so little variation in algal cover was evident within each lake, but visible differences in algal cover among lakes were pronounced. The logistics of sampling extremely remote lakes prevented us from sampling any GL lake more than once. We are confident that our sampling design could detect differences among GL lakes, but we cannot assess how closely our estimates approach growing-season averages. In the QC lake, each site consisted of $50 \mathrm{~m}$ of shoreline and was sampled 2 to $3 \times$ per summer. We collected rocks or wood at 0.5 - to $1.0-\mathrm{m}$ depth intervals along 3 evenly placed transects perpendicular to the shore. We transported GL and QC rock and wood substrata with their intact periphyton communities to the laboratory for further processing. In the laboratory, we removed epilithon or epixylon from the substrata by scrubbing them with a nylon brush. We diluted the resulting slurries to a known volume, and homogenized and subsampled them. We filtered the subsamples onto glass-fiber filters (Whatman GF/F), and froze the filters for chlorophyll analysis.

In the GL lakes, macrophytes consisted of several species of slow-growing mosses that grew diffusely throughout the entire water column and persisted for years (Caning and Rasch 2000, Vadeboncoeur et al. 2003). We hand-collected cuttings of moss and placed them in plastic bags. In the QC lake, we collected 3 replicates of each of 4 macrophyte taxa at each site. A SCUBA diver determined the depth distribution of each taxon visually, and collected one plant from the upper, middle, and lower $1 / 3$ of that distribution. A SCUBA diver gently lowered an acrylic tube (15.3- or $7.6-\mathrm{cm}$ inner diameter, covered at one end with $48-\mu \mathrm{m}-$ nitex mesh) over the entire macrophyte and sealed the plant in the tube. At the surface, we rinsed the contents of the tube into a plastic bag. We did not collect epiphyton in US lakes because the lakes did not contain macrophytes. In the laboratory, we removed the periphyton from GL and QC macrophytes with a soft brush and subsampled it as described above for periphyton on hard substrata.

We collected intact 0.5 -cm-deep sediment cores with a cut-off syringe to measure epipelon chlorophyll (Hansson 1988). We collected samples at 0.5- to 1.0-m depth intervals throughout the littoral zone on 3 (QC) or 4 (US) equally spaced transects. We did not collect sediment chlorophyll from GL lakes. We froze sediment samples for chlorophyll analysis and then freezedried them to prevent water from interfering with pigment analysis (Hansson 1988). We ground samples to a homogenous powder and subsampled them. Subsampling for chlorophyll analysis was particularly important in the US lakes where high organic content of sediments sometimes caused quenching of fluorometric readings.

\section{Chlorophyll analysis}

We extracted chlorophyll samples for $24 \mathrm{~h}$ in the refrigerator. We extracted phytoplankton, epixylon, and epipelon samples from the US lakes in 100\% methanol and analyzed the samples fluorometrically before and after acidification to a final concentration of $0.003 \mathrm{~N} \mathrm{HCl}$. We extracted samples from the GL lakes in $95 \%$ ethanol and analyzed the samples on a spectrophotometer at 665 and $750 \mathrm{~nm}$ without acidification. This method may have led to overestimation of chlorophyll in the GL lakes. We extracted samples from the QC lake in 95\% ethanol and analyzed the samples on a spectrophotometer at 665 and $750 \mathrm{~nm}$ before and after acidification. We used the equations of Marker et al. (1982) and a specific absorbance coefficient of 11.99 for ethanol to calculate chlorophyll concentrations.

\section{Primary productivity}

Primary productivity methods were consistent across studies and followed the ${ }^{14} \mathrm{C}$ methods of Revsbech et al. (1981) and Vadeboncoeur and Lodge (1998). We added ${ }^{14} \mathrm{C}$ to phytoplankton samples (collected in each region as described above), and incubated them in situ in biological $\mathrm{O}_{2}$ demand (BOD) bottles at 5 depths ( $n=2$ light bottles/depth and 2-5 dark bottles/productivity run). We filtered the water onto glass-fiber filters (Whatman GF/F) and dried the filters for $24 \mathrm{~h}$ at $60^{\circ} \mathrm{C}$. We collected intact periphyton communities in light and dark Plexiglas chambers within the depth ranges described for chlorophyll samples (above). We added ${ }^{14} \mathrm{C}$ and incubated chambers for $2 \mathrm{~h}$ in situ at the depth from which they were collected. We scrubbed epilithon, epixylon, and epiphyton from the substratum, and subsampled as described for chlorophyll analysis of these communities. We rinsed primary productivity filters with 0.1 $\mathrm{N} \mathrm{HCl}$, placed them in scintillation vials, and dried them for $24 \mathrm{~h}$ at $60^{\circ} \mathrm{C}$. We added scintillation fluor to dried filters, which we read on a scintillation counter with internal quench correction. We freeze-dried, ground, subsampled, suspended in scintillation gel, and counted sediment samples with epipelon (Vadeboncoeur and Lodge 1998).

\section{Nutrient and organic matter analysis}

We collected water for nutrient analysis as described for phytoplankton. We measured TP spectrophotemetrically after a persulfate digestion using estab- 
lished methods for monitoring programs in each country (Jeppesen et al. 1999, Carpenter et al. 2001). We subsampled QC sediment cores and dried $\left(60^{\circ} \mathrm{C}\right.$ for $24 \mathrm{~h})$ and ashed $\left(500^{\circ} \mathrm{C}\right.$ for $\left.1 \mathrm{~h}\right)$ them to determine organic matter content as ash-free dry mass (AFDM).

\section{Potential biases}

Our methods introduced a potential bias when either area-specific chlorophyll or productivity were compared across communities. We extracted chlorophyll from the entire sediment-periphyton complex, but scrubbing periphyton from rocks, wood, and macrophytes may not have removed all of the periphyton. However, we scrubbed hard substrata and macrophytes for both chlorophyll and productivity measurements and, assuming consistent effort, this procedure should have led to approximately equal biases for both chlorophyll and primary productivity of epilithon, epixylon, and epiphyton communities. Any underestimate should have been removed when chlorophyll-specific productivity was calculated. However, the scrubbing vs whole-extraction may have underestimated areal chlorophyll or areal productivity for epilithon/epixylon/epiphyton relative to epipelon.

We tested the efficiency of rock scrubbing to assess the potential effects of this bias on our results. We scrubbed very rough rocks that had only very thin, tightly adhered algal biofilms. This type of sample was not similar to the substrata in our study, but it did represent a worst-case scenario. In this test, we found that chlorophyll removed by scrubbing was only $60 \%$ of that removed by extracting the whole rock. Therefore, we ran statistics on the actual data and on data adjusted for a $40 \%$ underestimate when comparing area-specific chlorophyll or area-specific productivity among communities. However, we report all data without this correction factor because: 1) based on biofilm development, the study communities were very unlikely to have been underestimated by $40 \%$, and 2) scrubbing algae from surfaces is a standard approach (similar to filtering phytoplankton) and comparable to other studies.

\section{Data analysis}

Sites within Lake Memphremagog in the QC region had greater structural heterogeneity and were separated by greater physical distance ( $>3 \mathrm{~km}$ and up to 25 $\mathrm{km}$ ) than lakes within the GL or US regions. To reflect this level of variation, we treated individual sites in Lake Memphremagog as independent observations in the same way that we treated individual lakes as independent observations in the US and GL regions. For most analyses, we averaged data from each US and GL lake over the course of the summer so that an observation consisted of a lake-year. In the QC lake, we averaged data from each site over the course of the summer to produce an annual average per site.

We did statistical analyses with SAS, Procedure General Linearized Models (PROC GLM, version 9.1, SAS Institute, Cary, North Carolina). We log transformed data before analysis to homogenize variances. We used PROC GLM to regress periphyton and phytoplankton chlorophyll on TP with dummy variables to code for region (GL, QC, US). The effect of region was significant, so we ran the regression analysis a $2^{\text {nd }}$ time using only the QC and US data (temperate lakes; see below). We could not use a multivariate approach to assess the effects of other environmental factors on periphyton because withinregion variability in variables such as conductivity, $\mathrm{pH}$, and dissolved organic $\mathrm{C}$ (DOC) was very low in the temperate lakes. However, among-lake variability in chemical variables was more pronounced in GL (subarctic) lakes. Therefore, we did multiple regression to test for the effects of TP, TN, conductivity, and DOC in the subarctic lakes only.

We used correlation analysis to determine if epilithic and epixylic chlorophyll varied with phytoplankton chlorophyll and multiple regression to characterize variation in epipelic chlorophyll with sediment organic-matter content and water depth. We used a fixedeffects analysis of variance (ANOVA) to test the effects of region and substratum on area-specific productivity (epipelon and epixylon/epilithon). We used a 2-way fixed-effects ANOVA to test the effects of substratum and region on chlorophyll-specific productivity of all periphyton communities and phytoplankton. In this latter analysis, chlorophyll-specific productivity was unavailable for sediments in GL lakes and macrophytes in the US lakes; therefore, the missing components of the ANOVA reduced the degrees of freedom for the interaction term. We used a 1-way ANOVA to test for differences in epiphyton chlorophyll/g plant biomass among macrophyte taxa in Lake Memphremagog.

\section{Results}

\section{Chlorophyll}

Phytoplankton.-Phytoplankton chlorophyll was positively related to water-column TP across the entire geographic range of our study. However, the effect of the dummy variable for region was significant because the phytoplankton chlorophyll in the GL lakes was very low (Fig. 1A). When we ran the regression excluding the subarctic lakes, the model for pooled temperate (US, QC) lakes yielded an insignificant 

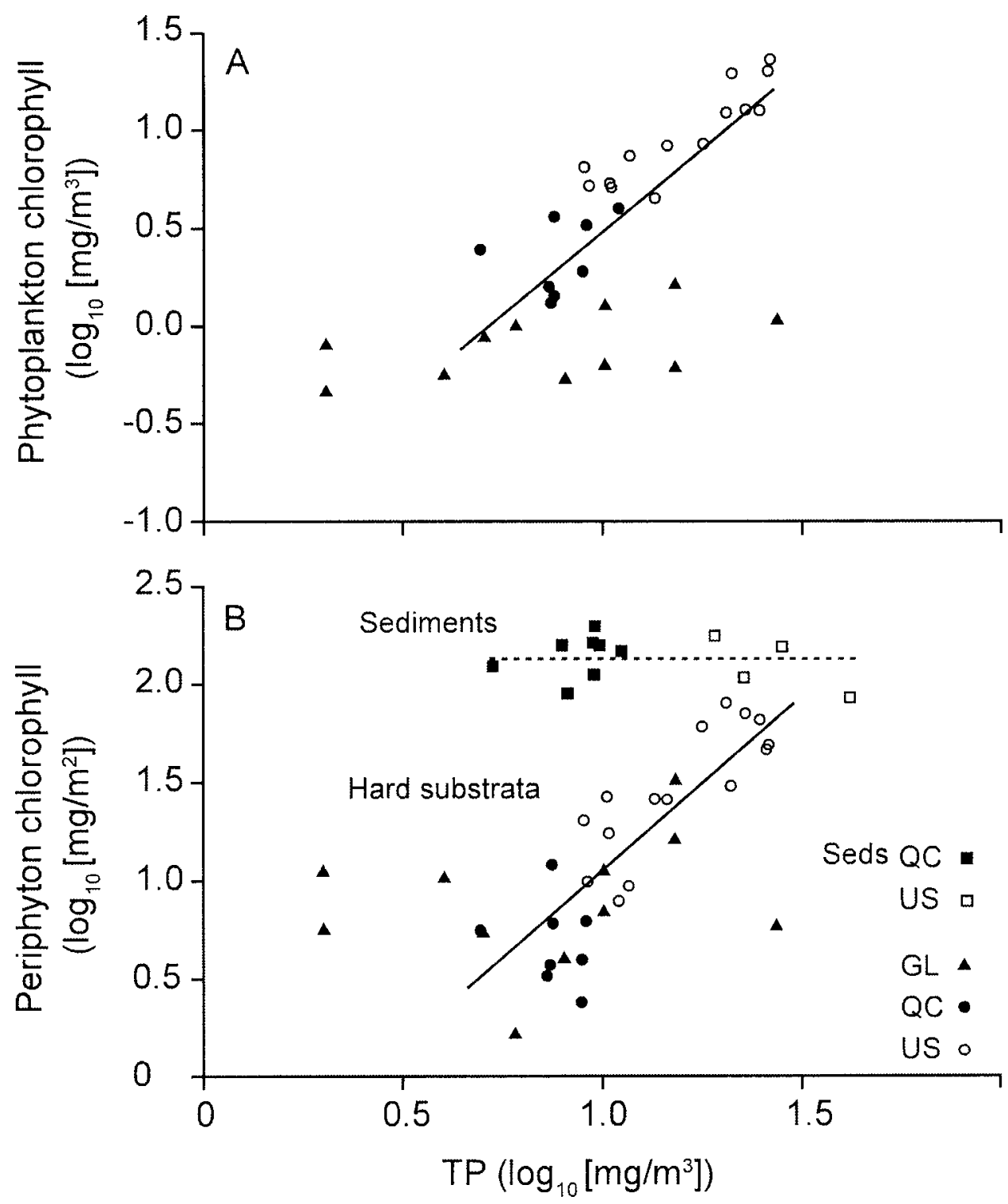

FIG. 1. Chlorophyll concentrations of phytoplankton (A), periphyton on hard substrata (epilithon/epixylon) and sediments (epipelon) (B) as a function of total P (TP) in lakes in Michigan (US), Greenland (GL), and Quebec, Canada (QC). Plotted lines are for temperate (US and QC) lakes only. Seds = sediments.

effect of the dummy variable (region), but the TP effect remained highly significant $\left(\log _{10}\right.$ [phytoplankton chlorophyll $]=1.49 \times \log _{10}[\mathrm{TP}]-0.94, F_{1,21}=82.8, p$ $<0.0001, R^{2}=0.80$; Fig. 1A). Phytoplankton in the subarctic lakes had a positive, but much weaker, relationship with TP (Fig. 1A).

Epilithon/epixylon.-Epilithon and epixylon communities were considered together as periphyton on hard substrata. Both the dummy variable (region) and TP had significant effects because of the poor fit for subarctic lakes. When the subarctic lakes were removed from the model, periphyton chlorophyll on hard substrata in pooled temperate lakes was strongly and significantly related to water-column TP $\left(\log _{10}\left[\right.\right.$ periphyton chlorophyll] $=1.79 \times \log _{10}[\mathrm{TP}]-$ $0.85, F_{1,21}=87.05, p<0.0001, R^{2}=0.81$; Fig. $\left.1 B\right)$. We used PROC GLM to compare the slopes of the temperate epilithon/epixylon- and phytoplanktonTP regressions and found that slopes of the 2 regression lines were significantly different $(p<0.03)$.

Other data (EJ, unpublished data) suggest that the subarctic lakes have high levels of particulate inorganic $P$ that is unavailable to the biota, but the remoteness and difficulty of sampling mean that we have no way of augmenting the data set or testing this hypothesis. However, if periphyton on hard substrata and phyto- 


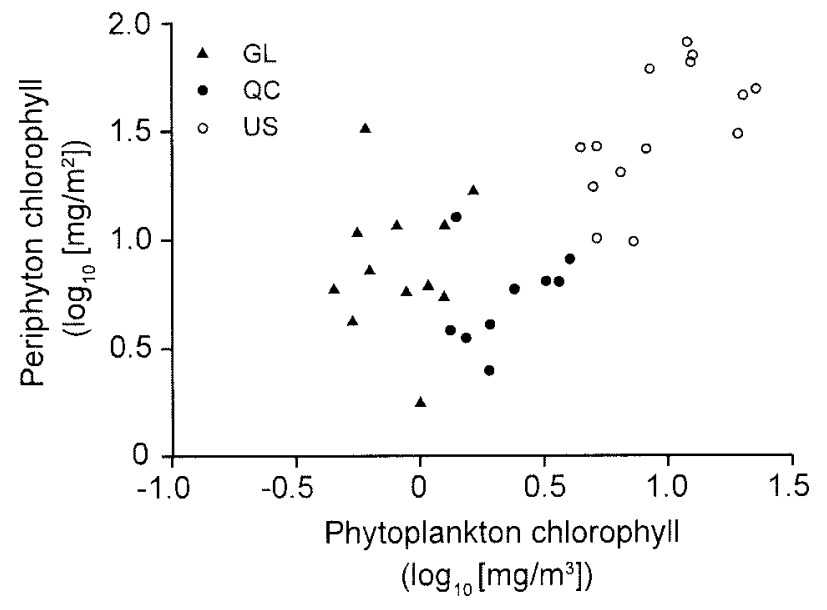

FIG. 2. Correlation between mean summer chlorophyll content of periphyton on hard substrata (epilithon/epixylon) and mean phytoplankton chlorophyll content in lakes in Michigan (US), Greenland (GL), and Quebec, Canada (QC).

plankton are limited by similar factors (e.g., bioavailable $\mathrm{P}$ ) then a positive correlation between the 2 communities is expected across all regions. Periphyton on hard substrata were positively correlated with phytoplankton chlorophyll in temperate lakes (Pearson correlation coefficient: $r=0.69, p<0.0001$; Fig. 2). However, chlorophyll concentrations on rocks in the subarctic lakes tended to be higher for a given phytoplankton concentration than was typical of temperate lakes. We further analyzed phytoplankton and periphyton chlorophyll concentrations in the subarctic lakes using multiple regression analysis. None of the potential predictor variables (TP, TN, DOC, specific conductance) had significant $(p>0.05)$ effects.

Epiphyton.-Epiphyton chlorophyll was measured only in the GL and QC lakes because the US lakes lacked macrophytes. Four taxa, Potamogeton robinsii, Myriophyllum spicatum, Potamogeton amplifolius, and Valisneria americana were present at each of 9 sites in the QC lake, but either M. spicatum or P. robinsii dominated plant biomass within most sites. Valisneria americana had

TABLE 1. Mean (SE) chlorophyll content of epiphyton on macrophytes in Lake Memphremagog, Quebec ( $n=9$ sites), and mosses in Greenland lakes ( $n=10$ lakes).

\begin{tabular}{lcc}
\hline \hline \multicolumn{1}{c}{ Taxon } & Sample site & $\begin{array}{c}\text { Chlorophyll } \\
\text { (mg/g macrophyte } \\
\text { dry mass) }\end{array}$ \\
\hline Valisneria americana & Memphremagog & $0.056(0.0066)$ \\
Potamogeton robinsii & Memphremagog & $0.201(0.031)$ \\
Potamogeton amplifolius & Memphremagog & $0.076(0.0083)$ \\
$\begin{array}{l}\text { Myriophyllum spicatum } \\
\text { Mosses }\end{array}$ & Memphremagog & $0.184(0.065)$ \\
& Greenland & $0.198(0.038)$ \\
\hline
\end{tabular}
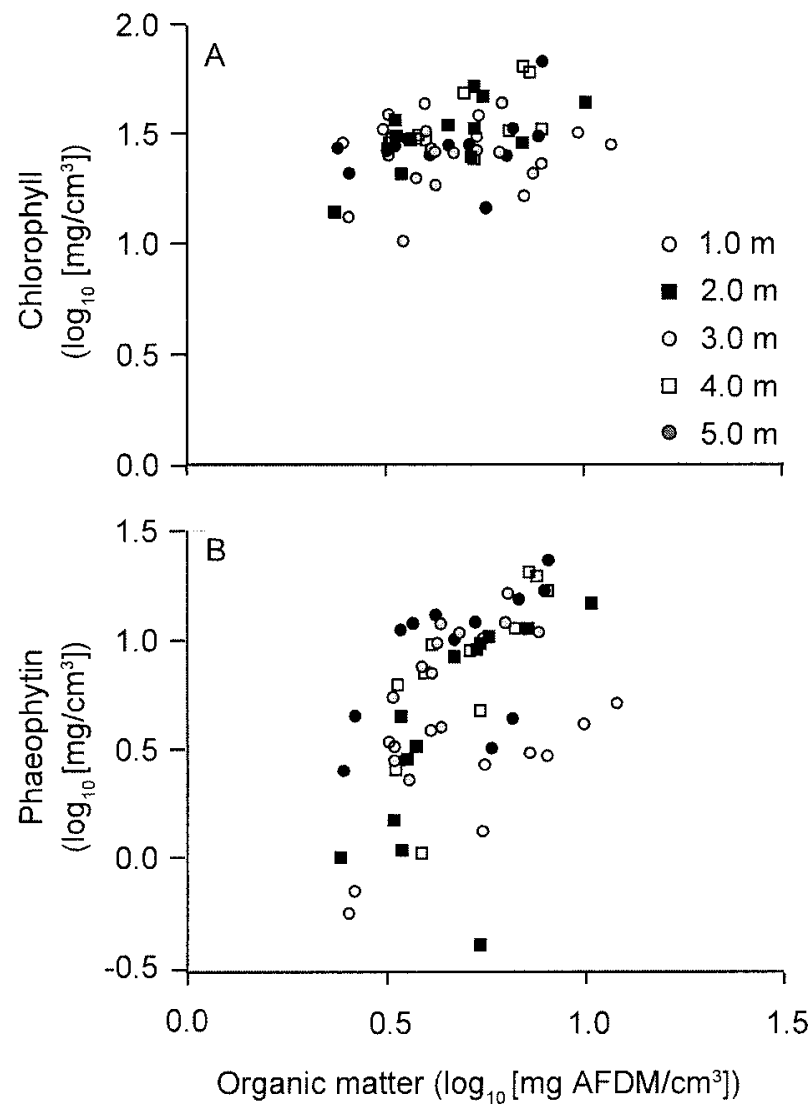

FIG. 3. Relationship between organic matter and chlorophyll (A) and phaeophytin (B) in sediments of Lake Memphremagog, Quebec. AFDM = ash-free dry mass.

significantly lower epiphyte chlorophyll than P. robinsii (ANOVA: $F_{3,28}=5.23, p=0.0054$; Table 1). Mean epiphyton chlorophyll/g macrophyte biomass was similar on $M$. spicatum and $P$. robinsii, but epiphyton concentrations were more variable on $M$. spicatum than on the other 3 species. Mean epiphyton chlorophyll/g moss biomass from the GL lakes was similar to concentrations on M. spicatum and P. robinsii (Table 1).

Epipelon.-Sediment chlorophyll concentrations were measured only in the temperate lakes. Chlorophyll on sediments ranged from 106 to $239 \mathrm{mg} / \mathrm{m}^{2}$ but was not related to water-column TP (Fig. 1B). We measured organic-matter content of the sediments in the QC lake, but we did not have diffusion samplers to measure porewater nutrients. Backwards elimination regression analysis demonstrated that sediment chlorophyll was weakly, but significantly, related to sediment organic matter, but was not affected by watercolumn depth $\left(R^{2}=0.12, F_{1,59}=7.76, p<0.01\right.$; Fig. $\left.3 \mathrm{~A}\right)$ In contrast, sediment phaeophytin concentration was correlated with sediment organic-matter content and increased with water depth $\left(\log _{10}[\right.$ phaeophytin] $=1.26$ 
$\times \log _{10}$ [sediment AFDM] $+0.13\left[\right.$ depth] $-0.51, R^{2}=$ $0.46, F_{2,58}=24.33, p<0.0001$; Fig. 3B).

\section{Primary productivity}

Area-specific productivity.-Neither phytoplankton nor epiphyton productivity could be expressed meaningfully on a $/ \mathrm{m}^{2}$-substratum basis. Each could have been expressed $/ \mathrm{m}^{2}$ lake surface area, but any patterns would have been driven by water depth (phytoplankton) or macrophyte biomass (epiphyton). Moreover, the entire water column of many of the GL lakes experienced $>10 \%$ light, making it impossible to do a meaningful among-lake comparison of phytoplankton productivity summed from $100 \%$ to $10 \%$ light. Therefore, we compared area-specific productivity only for unconsolidated sediments and rocks/wood. Region ( $p$ $=0.013)$ and substratum $(p<0.001)$ had significant effects on area-specific productivity without significant interaction $(p=0.91)$. Epipelon had consistently higher productivity than periphyton on hard substrata, and productivity in the US lakes was higher than in the QC or GL lakes (Tukey's Honestly Significant Difference [HSD], $p<0.05$, Fig. 4A). Accounting for the potential residual productivity left on hard substrata from scrubbing did not alter the significant differences in area-specific productivity between periphyton on hard substrata and epipelon.

Chlorophyll-specific productivity.-Chlorophyll-specific productivity could be compared for periphyton on hard substrata, epiphyton, epipelon, and phytoplankton. Region $(p<0.0004)$ and substratum $(p<0.0001)$ had significant effects on area-specific productivity without significant interaction $(p=0.18)$, indicating that variation in chlorophyll-specific productivity with substratum was consistent across the geographic range tested. For each substratum (where sampled), algal communities in GL lakes had the highest chlorophyllspecific productivity, whereas chlorophyll-specific productivity did not differ between the US and QC lakes (Tukey's HSD, $p<0.05$ ). Chlorophyll-specific productivity was highest for phytoplankton and lowest for epipelon. Periphyton on hard substrata and epiphyton had intermediate levels of chlorophyllspecific primary productivity (Fig. 4B). Phytoplankton had higher chlorophyll-specific productivity than periphyton on all substrata. In the overall ANOVA, phytoplankton and epiphyton chlorophyll-specific productivity were not significantly different (Tukey's HSD > 0.05), but this result was caused by the lack of epiphyton data for the US lakes. Phytoplankton had higher chlorophyll-specific productivity than epiphyton when the US lakes were eliminated from the ANOVA (Tukey's HSD < 0.05), and epiphyton and
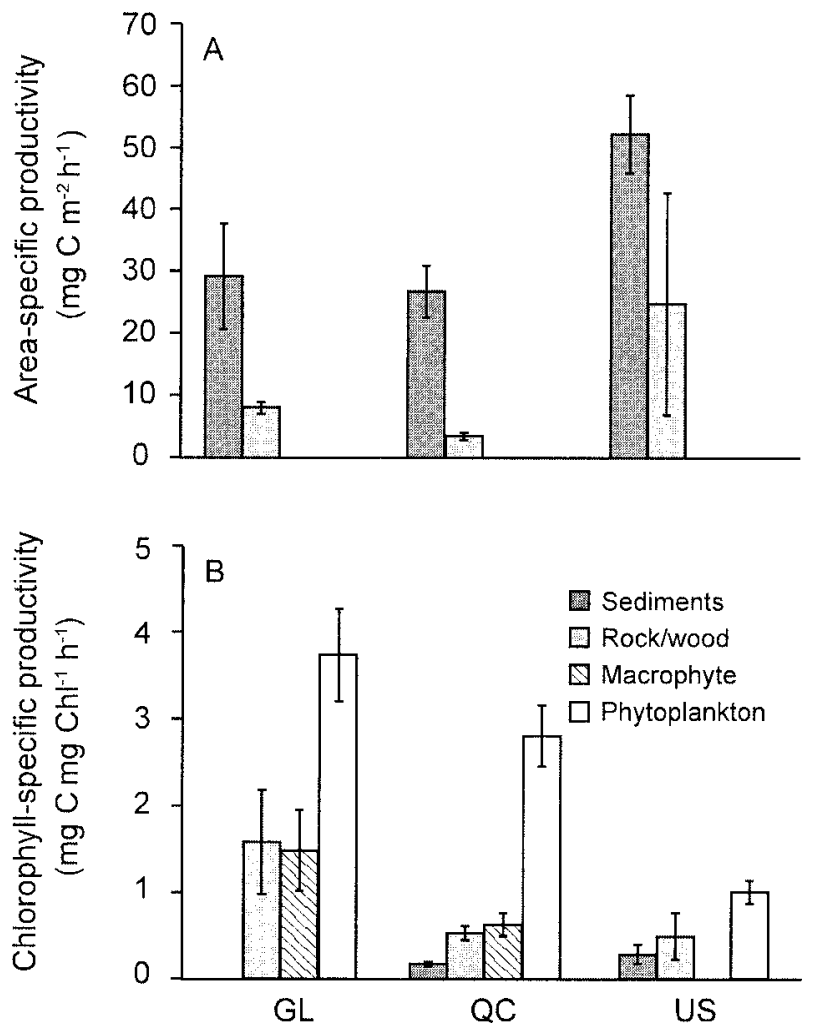

FIG. 4. Mean ( \pm 1 SE) area-specific productivity of periphyton on hard substrata (epilithon/epixylon) and sediments (epipelon) (A) and chlorophyll-specific productivity of algal communities on different substrata (B) in lakes in Michigan (US), Greenland (GL), and Quebec, Canada (QC). The high productivity on wood in the US lakes relative to lakes in the other 2 regions includes an increase in response to water-column fertilization. The high productivity on sediments in the US lakes was typical of rates both before and after fertilization (Vadeboncoeur et al. 2001). Sediments were not collected in Greenland lakes, and the US lakes had no macrophytes. $\mathrm{Chl}=$ chlorophyll.

periphyton on hard substrata were not significantly different (Tukey's HSD, $p<0.05$ ). Epipelon had significantly lower chlorophyll-specific productivity than all other communities. Again, there were no significant interaction effects, indicating that variation in chlorophyll-specific productivity with substratum was consistent across the geographic range tested.

\section{Discussion}

The heterogeneous composition of littoral zones imposes structural and chemical variability on attached algal communities that is reflected in biomass and productivity. Far from being a homogeneous entity, periphyton communities change markedly over spatial scales of centimeters to meters such as occur with changes in depth or substratum (Stevenson et al. 
1985, Burkholder 1996, Lowe 1996). Our data demonstrate differences in periphyton chlorophyll and productivity associated with differences in substratum that are consistent across broad geographic gradients. By restricting our analysis to communities experiencing relatively high light intensities, we isolated physical and chemical aspects of substrata that were independent of changes in substratum distribution with light. This approach is imperfect given the natural distribution of substrata. For instance, sediments were usually collected from deeper areas than rocks and wood, meaning that the light intensity experienced by epipelic algae was, on average, somewhat lower than that experienced by epilithic or epixylic assemblages. However, our data demonstrate significantly higher biomass and productivity on sediments relative to other substratum types (Figs 1,4).

\section{Chlorophyll and water-column TP}

Patterns in phytoplankton biomass and productivity have been a central concern of limnological research and provide a good baseline comparison for our exploration of patterns in periphyton. Many researchers have aggregated phytoplankton data over broad geographic scales and demonstrated a strong correlation between phytoplankton chlorophyll and TP (Dillon and Rigler 1974, Jones and Bachmann 1976, Prairie et al. 1989). The regression statistics for phytoplankton chlorophyll on TP in the temperate lakes were well within those reported from comparative studies worldwide (Kalff 2002). Overall, chlorophyll content of both periphyton on hard substrata and phytoplankton increased systematically across the TP gradient in temperate lakes, although the slopes of the 2 regression lines were significantly different based on analysis of covariance. In the shallow, subarctic lakes, the chlorophyll content of neither periphyton on hard substrata nor phytoplankton was as strongly related to TP as in the temperate lakes (Fig. 1A, B).

The similarity between phytoplankton and epilithon/epixylon responses to TP suggests that watercolumn $\mathrm{P}$ is a limiting resource for both algal communities in temperate lakes. Such a relationship has been elusive to find in previous survey studies of periphyton on natural substrata in lakes (Cattaneo 1987, Smith 1998), and TP generally is a poor predictor of periphyton chlorophyll on natural hard substrata in lakes (Cattaneo 1987). However, N, and to a lesser extent $\mathrm{P}$, explain a substantial portion of variability of benthic algal chlorophyll in stream ecosystems across broad geographic scales (Dodds et al. 2002). As with our study, important factors in detecting the chlor- ophyll-nutrient relationship in streams were compiling a large data set and sampling shallow sites.

Spatial and temporal variation in chlorophyll content was high in the temperate lakes, and intensive sampling was required to detect the response to fertilization in the US lakes (Vadeboncoeur et al. 2001). The significant relationship between periphyton chlorophyll and TP on hard substrata in the P-limited temperate lakes may have been a consequence of the consistently high-light environment of our shallow sites and the fact that we sampled temperate lakes intensively over the summer (Morin and Cattaneo 1992). We sampled the QC lake 2 to $3 \times$ during the summer at multiple depths and the US lakes 3 to $7 \times$ per y $(n=10$ samples/sampling period in each lake for each year).

In the subarctic lakes, the weak relationship between TP and both phytoplankton and periphyton chlorophyll content could reflect methodological shortcomings or real differences in the determinants of algal biomass. The remoteness of the subarctic lakes meant that sampling effort was lowest there. Each datum for the US and QC lakes represents a summer average, but the GL lakes were sampled only once. Furthermore, we did not correct for phaeophytin in GL lake samples. However, the algal mats in the GL lakes were clearly in the early phase of development after ice-out, and chlorophyll-specific productivity was very high. Therefore, we consider it highly unlikely that substantial amounts of phaeophytin confounded chlorophyll estimates.

Evidence from concurrent studies indicates that the GL lakes have high concentrations of particulate inorganic $\mathrm{P}$ that is not available for biotic uptake. This biologically unavailable $\mathrm{P}$ may have inflated the TP concentration relative to temperate lakes. However, if the chlorophyll content of both GL lake phytoplankton and epilithon were driven by $\mathrm{P}$ availability, and we simply overestimated bioavailable $\mathrm{P}$, then observed deviations from predictions based on the temperate model should have been similar for the 2 communities. They were clearly different (Fig. 2). Instead, GL lakes had high periphyton chlorophyll content and low phytoplankton chlorophyll concentrations relative to temperate lakes.

Periphyton on hard substrata were sampled from depths $<0.5 \mathrm{~m}$ in the temperate lakes (except at 2 sites in the QC lake). This depth corresponded to saturating light intensities, so the differences between regions cannot be attributed to the shallowness of the subarctic lakes. Other factors, such as differential effects of grazing or growing season on periphyton vs phytoplankton, may have contributed to the high chlorophyll content of periphyton relative to phytoplankton. For instance, zooplankton grazing has been implicated in 
low phytoplankton biomass in Greenland lakes (Jeppesen et al. 2001). Daphnia pulex is abundant in fishless subarctic lakes and exert strong top-down control on the phytoplankton (Jeppesen et al. 2003).

In contrast to periphyton on hard substrata, no relationship could be detected between chlorophyll content of epipelon and water-column TP. Experimental evidence and other surveys across lake trophic gradients also have shown the absence of a relationship between epipelic chlorophyll content and watercolumn TP (Hansson 1992, Vadeboncoeur and Lodge 2000). Epilithic communities responded significantly to nutrient amendments during an in situ experiment in a Swedish lake, whereas communities on unconsolidated sediments did not (Hillebrand and Kahlert 2001, 2002). The lack of a relationship between epipelic chlorophyll content and water-column nutrient concentrations probably is a result of the high availability of nutrients associated with the interstitial water of sediments (Hagerthey and Kerfoot 1998, Vadeboncoeur and Lodge 2000).

The importance of substratum to acquisition of inorganic nutrients may not be limited to $\mathrm{N}$ and $\mathrm{P}$. Epilithic communities in soft-water lakes can be limited by availability of dissolved inorganic C (DIC; Turner et al. 1994), but the interstitial water can be an important source of DIC for epipelon (Vadeboncoeur and Lodge 1998). Most studies of lake periphyton focus on epilithon or epiphyton, and many use artificial substrata (Cattaneo and Amireault 1992). The high chlorophyll content and productivity associated with epipelon, along with the unique sediment nutrient environment, mean that models developed for epilithon and epiphyton are not transferable to epipelon. Unconsolidated sediments make up a substantial, and often the largest, proportion of littoralzone surface areas. Caution should be exercised when assessing the role of periphyton in lake-nutrient and energy dynamics by extrapolating processes from hard substrata to the entire littoral zone.

We could not relate epiphytic chlorophyll content to TP because macrophytes were present in only a small subset of our study lakes. However, the macrophyteepiphyton complex is one aspect of periphytonsubstratum interactions that has received a substantial amount of research attention (Cattaneo and Kalff 1979, Michelutti et al. 2003). In our study, chlorophyll content/unit biomass was similar for all plant species except for $V$. americana. Other researchers also have also found that $V$. americana has low epiphytic chlorophyll content relative to other taxa (Cattaneo and Kalff 1980). The similarity among the other species suggests that structure of the plant was not a strong determinant of chlorophyll content on macrophytes in our study lakes
(Table 1). This finding is similar to the results of other researchers who have found that macrophyte architecture is important for epiphyte load, but it is less important than other environmental variables, especially light (Lalonde and Downing 1991).

\section{Primary productivity}

Chlorophyll content is used widely as an indicator of algal biomass and, by inference, productivity. Chlorophyll content is easy to measure and it has been used successfully in studies of phytoplankton. But can chlorophyll be used effectively to compare contributions of different algal communities to autotrophic productivity within a lake? Chlorophyll contents on sediments were 5 to $100 \times$ greater than chlorophyll contents on rocks and wood (Table 2, Fig. 1B). We restricted our analysis to relatively highlight environments to avoid collecting periphyton communities that had increased biomass-specific chlorophyll to compensate for low light availability. Higher chlorophyll content on sediments than on rocks appears to be typical of high-light environments and has been noted in diverse lakes from Northern Europe to Africa (Table 2). The pattern is intriguing, but how does it relate to patterns in productivity?

Chlorophyll-specific productivity differed significantly among communities on different substrata. Phytoplankton had higher chlorophyll-specific productivity than epixylon, epilithon, and epipelon. Phytoplankton has the most diffuse growth form and, therefore, experiences less self-shading and has greater light-harvesting efficiencies than other communities (Krause-Jensen and Sand-Jensen 1998). Chlorophyll-specific productivity was similar on macrophytes and hard substrata (Fig. 4B). The gross structures of the mats on macrophytes and hard substrata were similar and consisted of thin, diffuse brownish biofilms usually $<2 \mathrm{~mm}$ thick. Area-specific productivity of epipelon was higher than area-specific productivity of periphyton on hard substrata in all 3 regions (Fig. 4A), but the magnitude of the difference in area-specific productivity between substrata was lower than expected because chlorophyll-specific productivity of epipelon was lower than chlorophyllspecific productivity of periphyton on hard substrata (Fig. 4B). These differences in chlorophyll-specific productivity are consistent with a progression of decreasing light attenuation within algal communities themselves. Compact algal mats on sediments attenuate light over shorter distances than diffusely structured algal communities on hard substrata and macrophytes, which in turn attenuate light over 
TABLE 2. Mean (SE) chlorophyll content of periphyton on hard substrata (epilithon/epixylon) and unconsolidated sediments (epipelon) in lakes. * indicates approximate range when values were read from a graph, - indicates data not available.

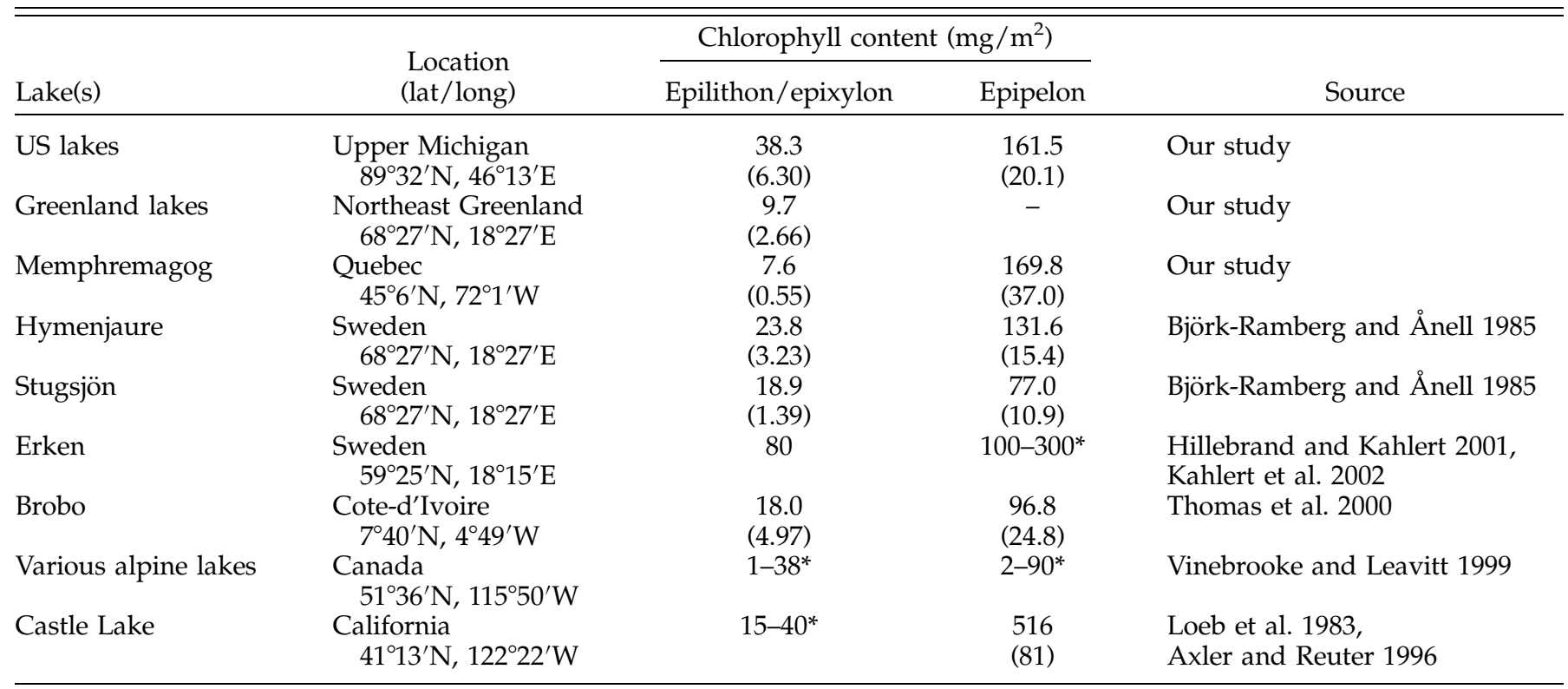

shorter distances than suspended planktonic communities (Krause-Jensen and Sand-Jensen 1998).

The significant variation in chlorophyll-specific productivity among communities on different substrata means that chlorophyll is an inadequate index of the relative contributions of these communities to whole littoral-zone primary production. Furthermore, if light attenuation within the algal mat is a strong driver of this variation, then chlorophyll-specific productivity within a particular community is likely to vary seasonally with changes in the physical structure of the algal mat. Last, differences in chlorophyll-specific productivity probably also reflect differences in species composition of the different littoral communities (Michelutti et al. 2003). We collected species-composition data only for the US lakes, and analysis of those data showed that taxonomic overlap among habitats was slight (YV, unpublished data). Phytoplankton communities were dominated by chrysophytes, dinoflagelates, cryptophytes, and filamentous cyanobacteria (Anabaena and Oscillatoria) depending on nutrient loading (Cottingham and Carpenter 1998, Cottingham et al. 1998). Epixylon communities consisted of stalked diatoms, filamentous green algae, and colonial cyanobacteria. Epipelon community composition changed with depth but was dominated by pennate diatoms, filamentous cyanobacteria (Lyngbya and Oscillatoria), and chlorophytes (desmids) (YV, unpublished data).

Rapid light attenuation through epipelic mats or the accumulation and burial of undegraded chlorophyll in deeper, inactive layers of the mat may be responsible for low chlorophyll-specific productivity in epipelic communities. Shallow sandy sediments typically had a thin crust of adnate algae, but algal mats on organic sediments had a more-layered structure with an active green surface layer overlying a senescent brown or gray stratum. Thus, phaeophytin increased both with water depth and sediment organic matter content, although chlorophyll showed only a weak positive relationship with sediment organic-matter content (Fig. 3). The pattern suggests that epipelon on shallow inorganic sediment is either more heavily grazed or more completely decomposed than epipelon on organic sediment. The morphology of epipelic mats, in which living cells overgrow older mats, almost certainly gives rise to an overestimation of active chlorophyll on sediments.

However, low chlorophyll-specific productivity in epipelic communities should not be attributed entirely to the presence of undegraded chlorophyll. Kairesalo (1980) found low biomass-specific productivity of epipelon relative to epiphyton and phytoplankton in a Swedish lake using cell biovolume (rather than chlorophyll) as an estimate of algal biomass. Rapid light attenuation through dense epipelic mats (Kuhl and Jorgensen 1992, Dodds et al. 1999) results in low chlorophyll-specific primary productivity (Liboriussen and Jeppesen 2003, Vadeboncoeur et al. 2003) but high area-specific productivity in epipelon relative to phytoplankton (Krause-Jensen and Sand-Jensen 1998), as we saw in our study. 


\section{Periphyton and lake nutrient and energy dynamics}

It is becoming increasingly apparent that periphyton make critical contributions to lake food webs, but attached algal communities have yet to be fully integrated into conceptual and empirical models of lake nutrient and energy dynamics. The complexity of littoral habitats is an impediment to such an integration, but our data show that predictable relationships among different algal communities exist across broad spatial scales, at least in relatively transparent lakes. The substratum-specific patterns of chlorophyll and productivity demonstrated here are corroborated by local and regional data from other lakes (Kairesalo 1980, Björk-Ramberg and Ånell 1985, Hansson 1992, Vinebrooke and Leavitt 1999, Thomas et al. 2000, Havens et al. 2001; Table 2). We restricted our analysis to well-lit habitats, but data-based models that incorporate the effects of turbidity on productivity of different periphyton communities are needed. The development of such models can then be followed by an integration of substrate distribution and lake morphometry into predictions of whole-lake primary production. The patterns revealed in our study demonstrate that littoral-zone heterogeneity need not pose an insurmountable hurdle to quantifying the role of periphyton in whole-lake primary production and food webs. Rather, such heterogeneity may be critical to supporting diverse communities of littoral consumers.

\section{Acknowledgements}

We thank the many undergraduate assistants and technicians who helped with our study. We also thank David Lodge, Steve Carpenter, and Jim Kitchell who spearheaded the whole-lake manipulations on the US lakes. Our work was supported by the US National Science Foundation, the Danish Natural Science Research Council, and a GRIL postdoctoral fellowship funded by the Quebec Research Foundation (FCAR) to YV.

\section{Literature Cited}

Axler, R. P., AND J. E. Reuter. 1996. Nitrate uptake by phytoplankton and periphyton: whole-lake enrichments and mesocosm ${ }^{15} \mathrm{~N}$ experiments in an oligotrophic lake. Limnology and Oceanography 41:659-671.

BJöRK-RAMBERG, S., AND C. ÅNELL. 1985. Production and chlorophyll concentration of epipelic and epilithic algae in fertilized and unfertilized subarctic lakes. Hydrobiologia 126:213-219.

BURKHOLDER, J. M. 1996. Interactions of benthic algae with their substrata. Pages 253-297 in R. J. Stevenson, M. L. Bothwell, and R. L. Lowe (editors). Algal ecology: freshwater benthic ecosystems. Academic Press, San Diego, California.
Burkholder, J. M., AND R. G. Wetzel. 1989. Epiphytic microalgae on a natural substratum in a phosphoruslimited hardwater lake: seasonal dynamics of community structure, biomass and ATP content. Archiv für Hydrobiologie Supplementband 83:1-56.

BurKHOLDER, J. M., AND R. G. WeTZEL. 1990. Epiphytic alkaline phosphatase activity on natural and artificial plants in a P-limited lake: re-evaluation of the role of macrophytes as a phosphorus source for epiphytes. Limnology and Oceanography 35:736-746.

CANING, K., AND M. RASCH. 2000. Zackenberg ecological research operations. $5^{\text {th }}$ annual report, 1999. Danish Polar Center, Ministry of Research and Information Technology, Copenhagen, Denmark. (Available from: http:/ / www.zackenberg.dk/documents/publications / ZAR1999.pdf)

CARIGnAN, R., AND J. KALFF. 1982. Phosphorus release by submerged macrophytes - significance to epiphyton and phytoplankton. Limnologv and Oceanography 27:419427.

Carlton, R. G., and R. G. Wetzel. 1988. Phosphorus flux from lake sediments: effect of epipelic algal oxygen production. Limnology and Oceanography 33:562-570.

Carpenter, S. R., J. J. Cole, J. R. Hodgson, J. F. Kitchell, M. L. Pace, D. Bade, K. L. Cottingham, T. E. Essington, J. N. Houser, AND D. E. Schindler. 2001. Trophic cascades, nutrients, and lake productivity: whole-lake experiments. Ecological Monographs 71:163-186.

Carpenter, S. R., And J. F. Kitchell. 1993. The trophic cascade in lakes. Cambridge University Press, New York.

Cattaneo, A. 1987. Periphyton in lakes of different trophy. Canadian Journal of Fisheries and Aquatic Sciences 44: 296-303.

Cattaneo, A., and M. C. Amireault. 1992. How artificial are artificial substrata for periphyton? Journal of the North American Benthological Societv 11:244-256.

Cattaneo, A., AND J. KalfF. 1979. Primary production of algae growing on natural and artificial aquatic plants: a study of interaction between epiphytes and their substrate. Limnology and Oceanography 24:1031-1037.

CATtAneO, A., AND J. KAlFF. 1980. The relative contribution of aquatic macrophytes and their epiphytes to the production of macrophyte beds. Limnology and Oceanography 25:280-289.

Cottingham, K. L., and S. R. Carpenter. 1998. Population, community, and ecosystem variates as ecological indicators: phytoplankton responses to whole-lake enrichment. Ecological Applications 8:508-530.

Cottingham, K. L., S. R. Carpenter, and A. L. St. Amand. 1998. Responses of epilimnetic phytoplankton to experimental nutrient enrichment in three small seepage lakes. Journal of Plankton Research 20:1889-1914.

Dillon, P. J., AND F. H. Rigler. 1974. The phosphoruschlorophyll relationship in lakes. Limnology and Oceanography 19:767-773.

Dodds, W. K., B. J. F. Biggs, And R. L. Lowe. 1999. Photosynthesis-irradiance patterns in benthic microalgae: variations as a function of assemblage thickness and community structure. Iournal of Phycology 35:42-53. 
Dodds, W. K., V. H. Smith, And K. Lohman. 2002. Nitrogen and phosphorus relationships to benthic algal biomass in temperate streams. Canadian Journal of Fisheries and Aquatic Sciences 59:865-874.

Hagerthey, S. E., AND W. C. KerfoOt. 1998. Groundwater flow influences the biomass and nutrient ratios of epibenthic algae in a north temperate seepage lake. Limnology and Oceanography 43:1227-1242.

HANSSON, L.-A. 1988. Chlorophyll $a$ determination of periphyton on sediments: identification of problems and recommendation of method. Freshwater Biology 20: 347-352.

HANSSON, L.-A. 1992. Factors regulating periphytic algal biomass. Limnology and Oceanography 37:322-328.

Havens, K. E., J. Hauxwell, A. C. Tyler, S. Thomas, K. J. McGlathery, J. Cebrian, I. Valiela, A. D. Steinman, and S.-J. Hwang. 2001. Complex interactions between autotrophs in shallow marine and freshwater ecosystems: implications for community responses to nutrient stress. Environmental Pollution 113:95-107.

Hecky, R. E., and R. H. Hesslein. 1995. Contributions of benthic algae to lake food webs as revealed by stable isotope analysis. Iournal of the North American Benthological Society 14:631-653.

Hillebrand, H., AND M. KAHLERT. 2001. Effect of grazing and nutrient supply on periphyton biomass and nutrient stoichiometry in habitats of different productivity. Limnology and Oceanography 46:1881-1898.

HilleBRAND, H., AND M. KAHLERT. 2002. Effect of grazing and water column nutrient supply on biomass and nutrient content of sediment microalgae. Aquatic Botany 72:143159.

Jeppesen, E., K. Christoffersen, F. Landkildehus, T. Lauridsen, AND S. AMsinck. 2001. Fish and crustaceans in northeast Greenland lakes with special emphasis on interactions between Arctic char (Salvelinus alpinus), Lepidurus arcticus, and benthic chydorids. Hydrobiologia 442:329-337.

Jepresen, E., J. P. Jensen, C. Jensen, B. FaAfeng, P. Brettum, D. Hessen, M. SøndergaArd, T. L. Lauridsen, and K. Christoffersen. 2003. The impact of nutrient state and lake depth on top-down control in the pelagic zone of lakes: study of 466 lakes from the temperate zone to the arctic. Ecosystems 6:313-325.

Jeppesen, E., J. P. Jensen, M. Søndergaard, and T. Lauridsen. 1999. Trophic dynamics in turbid and clearwater lakes with special emphasis on the role of zooplankton for water clarity. Hydrobiologia 408/409:217-231.

Jones, J. I., B. Moss, AND J. O. Young. 1997. Interactions between periphyton, nonmolluscan invertebrates and fish in standing freshwaters. Pages 69-90 in E. Jeppesen, M. Søndergaard, M. Søndergaard, and K. Christoffersen (editors). The structuring role of submerged macrophytes in lakes. Springer Verlag, New York.

Jones, J. I., J. O. Young, J. W. Eaton, And B. Moss. 2002. The influence of nutrient loading, dissolved inorganic carbon and higher trophic levels on the interaction between submerged plants and periphyton. Iournal of Ecology 90: 12-24.

Jones, J. R., AND R. W. BACHMAnN. 1976. Prediction of phosphorus and chlorophyll levels in lakes. Journal of the Water Pollution Control Federation 48:2176-2182.

Kahlert, M., A. T. Hasselrot, H. Hillebrand, and K. PetTERSSON. 2002. Spatial and temporal variation in the biomass and nutrient status of epilithic algae in Lake Erken, Sweden. Freshwater Biology 47:1191-1215.

Kairesalo, T. 1980. Comparison of in situ photosynthetic activity of epiphytic, epipelic and planktonic algal communities in an oligotrophic lake, southern Finland. Journal of Phycology 16:57-62.

KaLfF, J. 2002. Limnology: inland water ecosystems. PrenticeHall, Upper Saddle River, New Jersey.

Krause-Jensen, D., AND K. SAND-Jensen. 1998. Light attenuation and photosynthesis of aquatic plant communities. Limnology and Oceanography 43:396-407.

KuHL, M., AND B. B. Jorgensen. 1992. Spectral light measurements in microbenthic phototrophic communities with a fiberoptic microprobe coupled to a sensitive diode-array detector. Limnology and Oceanography 37:1813-1823.

LALONDE, S., AND J. A. DownING. 1991. Epiphyton biomass is related to lake trophic status, depth, and macrophyte architecture. Canadian Journal of Fisheries and Aquatic Sciences 48:2285-2291.

Liboriussen, L., AND E. JePPESEN. 2003. Temporal dynamics in epipelic, pelagic and epiphytic algal production in a clear and a turbid shallow lake. Freshwater Biology 48:418431.

Loeb, S. L. 1981. An in situ method for measuring the primary productivity and standing crop of the epilithic periphyton community in lentic systems. Limnologv and Oceanography 26:394-399.

Loeb, S. L., J. E. Reuter, and C. R. Goldman. 1983. Littoral zone production of oligotrophic lakes. Pages 161-167 in R. G. Wetzel (editor). Periphyton of freshwater ecosystems. Dr. W. Junk, The Hague, The Netherlands.

LowE, R. L. 1996. Periphyton patterns in lakes. Pages 57-76 in R. J. Stevenson, M. L. Bothwell, and R. L. Lowe (editors). Algal ecology: freshwater benthic ecosystems. Academic Press, San Diego, California.

Marker, A. F. H., E. A. Nusch, and B. Riemann. 1982. The measurement of photosynthetic pigments in freshwaters and standardization of methods: conclusions and recommendations. Archiv für Hydrobiologie Beiheft Ergebnisse der Limnologie 14:91-106.

Michelutti, N., A. J. Holtham, M. S. V. Douglas, and J. P. SMOL. 2003. Periphytic diatom assemblages from ultraoligotrophic and UV transparent lakes and ponds on Victoria Island and comparisons with other diatom surveys in the Canadian Arctic. Iournal of Phycology 39:465-480.

Morin, A., AND A. CATTANEO. 1992. Factors affecting sampling variability of fresh-water periphyton and the power of periphyton studies. Canadian Iournal of Fisheries and Aquatic Sciences 49:1695-1703.

Nydick, K. R., B. M. Lafrancois, J. S. Baron, and B. M. JoHNSON. 2004. Nitrogen regulation of algal biomass, productivity, and composition in shallow mountain lakes, Snowy Range, Wyoming, USA. Canadian Journal of Fisheries and Aquatic Sciences 61:1256-1268. 
Prairie, Y. T., C. M. Duarte, and J. KalfF. 1989. Unifying nutrient-chlorophyll relationships in lakes. Canadian Journal of Fisheries and Aquatic Sciences 46:1176-1182.

PRINGLE, C. M. 1990. Nutrient spatial heterogeneity: effects on community structure, physiognomy and diversity of stream algae. Ecology 71:905-920.

Revsbech, N. P., B. B. Jørgensen, And O. Brix. 1981. Primary production of microalgae in sediments measured by oxygen microprofile, $\mathrm{H}^{14} \mathrm{CO}_{3}^{-}$fixation, and oxygen exchange methods. Limnology and Oceanography 25: 717-730.

Rooney, N., J. KalfF, AND C. Habel. 2003. The role of submerged macrophyte beds in phosphorus and sediment accumulation in Lake Memphremagog, Quebec, Canada. Limnology and Oceanography 48:1927-1937.

RowAN, D. J., J. KalfF, AND J. B. RasmussEN. 1992. Estimating the mud deposition boundary depth in lakes from wave theory. Canadian Journal of Fisheries and Aquatic Sciences 49:2490-2497.

SAND-JENSEN, K., AND J. BORUM. 1991. Interactions among phytoplankton, periphyton, and macrophytes in temperate freshwaters and estuaries. Aquatic Botany 41:137175.

Sмiтh, V. H. 1998. Cultural eutrophication of inland, estuarine, and coastal waters. Pages 7-49 in M. L. Pace and P. M. Groffman (editors). Successes, limitations, and frontiers in ecosystem science. Springer, New York.

Stevenson, R. J., R. Singer, D. A. Roberts, And C. W. Boylen. 1985. Patterns of epipelic algal abundance with depth, trophic status, and acidity in poorly buffered New Hamshire lakes. Canadian Iournal of Fisheries and Aquatic Sciences 42:1501-1512.

Thomas, S., P. Cecchi, D. Corbin, And J. Lemoalle. 2000. The different primary producers in a small African tropical reservoir during a drought: temporal changes and interactions. Freshwater Biology 45:43-56.

Turner, M. A., E. T. Howell, G. G. C. Robinson, P. Campbell, R. E. HeCKY, AND E. U. SCHINDLER. 1994. Roles of nutrients in controlling growth of epilithon in oligotrophic lakes of low alkalinity. Canadian Journal of Fisheries and Aquatic Sciences 51:2784-2793.

Vadeboncoeur, Y., E. Jeppesen, M. J. Vander Zanden, H.-H. Schierup, K. Christoffersen, and D. M. Lodge. 2003. From
Greenland to green lakes: cultural eutrophication and the loss of benthic energy pathways in lakes. Limnology and Oceanography 48:1408-1418.

VAdeboncoeur, Y., AND D. M. Lodge. 1998. Dissolved inorganic carbon sources for epipelic algal production: sensitivity of primary production estimates to spatial and temporal distribution of ${ }^{14} \mathrm{C}$. Limnology and Oceanography 43:1222-1226.

Vadeboncoeur, Y., And D. M. Lodge. 2000. Periphyton production on wood and sediment: substratum-specific response to laboratory and whole-lake manipulations. Iournal of the North American Benthological Societv 19: 68-81.

Vadeboncoeur, Y., D. M. Lodge, and S. R. Carpenter. 2001. Whole-lake fertilization effects on distribution of primary production between benthic and pelagic habitats. Ecology 82:1065-1077.

VinEBRoOKE, R. D., AND P. R. LEAVITT. 1998. Direct and interactive effects of allochthonous dissolved organic matter, inorganic nutrients, and ultraviolet radiation on an alpine littoral food web. Limnology and Oceanography 43:1065-1081.

VinebroOKe, R. D., AND P. R. LeavitT. 1999. Phytobenthos and phytoplankton as potential indicators of climate change in mountain lakes and ponds: a HPLC-based pigment approach. Iournal of the North American Benthological Society 18:15-33.

WetZeL, R. G. 2001. Limnology: lake and river ecosystems. $3^{\text {rd }}$ edition. Academic Press, San Diego, California.

Wurtsbaugh, W. A., H. P. Gross, P. Budy, And C. Luecke. 2001. Effects of epilimnetic versus metalimnetic fertilization on the phytoplankton and periphyton of a mountain lake with deep chlorophyll maxima. Canadian Journal of Fisheries and Aquatic Sciences 58:2156-2166.

Yallop, M. L., D. M. PAterson, AND P. Wellsbury. 2000. Interrelationships between rates of microbial production, exopolymer production, microbial biomass, and sediment stability in biofilms of intertidal sediments. Microbial Ecology 39:116-127.

Received: 29 June 2005 Accepted: 29 December 2005 